\title{
Evidence that dietary supplementation with carotenoids and carotenoid-rich foods modulates the DNA damage : repair balance in human lymphocytes
}

\author{
Siân B. Astley ${ }^{1 *}$, Ruan M. Elliott ${ }^{1}$, David B. Archer ${ }^{2}$ and Susan Southon ${ }^{1}$ \\ ${ }^{1}$ Institute of Food Research, Norwich Research Park, Colney, Norwich NR4 7UA, UK \\ ${ }^{2}$ School of Life and Environmental Sciences, University Park, University of Nottingham, Nottingham NG7 2RD, UK
}

(Received 13 May 2003 - Revised 6 August 2003 - Accepted 16 August 2003)

Epidemiological evidence has shown that the habitual consumption of diets high in fruits and vegetables is associated with reduced risk of cancers. The challenge is to identify causal mechanisms of effect. The aim of the current study was to determine whether an increase in rate of removal of DNA single-strand breaks (SSB) following oxidative challenge could be provoked ex vivo in peripheral blood lymphocytes (PBL). The PBL were isolated from apparently healthy volunteers following dietary intervention with: (1) a mixed carotene capsule; (2) a daily portion of cooked minced carrots; (3) a matched placebo; (4) a portion of mandarin oranges; (5) vitamin C tablets. Single-cell gel electrophoresis was employed to measure baseline levels of SSB and DNA susceptibility to oxidative damage, and to monitor the number of SSB over $4 \mathrm{~h}$, in both unchallenged and $\mathrm{H}_{2} \mathrm{O}_{2}$-treated PBL. The enzymatic capacity for repair of different types of DNA oxidative lesions was also measured using two related cell-free assays. There was no evidence that any of the dietary supplementation regimens altered baseline levels of SSB, provided any direct antioxidant protection or altered DNA repair capacity, with two exceptions: the number of SSB following exposure to $\mathrm{H}_{2} \mathrm{O}_{2}$ decreased more rapidly in PBL from volunteers given the mixed carotene capsules and repair patch synthesis activity in PBL increased from volunteers given the cooked carrots. These results suggest that carotenoids and carotenoidrich foods can influence DNA damage:repair by modulation of discrete stages in the DNA repair mechanisms.

Carotenoids: $\beta$-Carotene: $\beta$-Cryptoxanthin: DNA damage: DNA repair: Single-cell gel electrophoresis

In the light of strikingly consistent observations from many epidemiological studies, there can be little doubt that the habitual consumption of diets high in fruits and vegetables helps to reduce the risk of development of degenerative diseases, including many types of cancers (Block et al. 1992; Byers \& Perry, 1992; World Cancer Research Fund, 1997). The challenges are to identify the food components responsible for these effects, to elucidate their mechanisms of action and to determine the dietary amounts of these agents that provide optimal health benefits.

To a great extent, the focus of attention has fallen on compounds present in foods that possess inherent antioxidant capacity. The basis for this is: (1) evidence that oxidative damage to cell constituents plays a central role in many degenerative processes (Ames, 1989; Guyton \& Kensler, 1993; Wiseman \& Halliwell, 1996); (2) the hypothesis that natural antioxidants in the diet help to limit the accumulation of such damage, thereby providing a degree of protection (Halliwell, 1994). It is, however, increasingly apparent that dietary antioxidants and other food components possess bioactivities that may influence the processes of disease development in other ways.
In the context of cancer and ageing, several studies suggest that dietary antioxidants, such as vitamin $\mathrm{C}$ and the carotenoids, may regulate DNA repair processes (Cooke et al. 1998; Fillion et al. 1998; Torbergsen \& Collins, 2000). It is not certain whether the direct antioxidant protection they may afford cellular DNA is more or less important than the effects they may have on DNA repair processes, or even whether either is genuinely physiologically significant in a healthy individual.

The present study follows on from earlier experiments in which we demonstrated that in vitro supplementation of Molt-17 cells (a human lymphocyte cell line) with various carotenoids provoked an increase in the rate of disappearance of DNA single-strand breaks (SSB) produced by oxidative challenge (Astley et al. 2002). Our results were consistent with a carotenoid-induced stimulation of DNA SSB repair, but other researchers have suggested that such an effect might be due to enhanced protection of the DNA from ongoing damage over the course of the experiment (i.e. a direct antioxidant protection provided by the carotenoid within the cells) (Fillion et al. 1998; Torbergsen \& Collins, 2000). These two potential mechanisms need not be mutually exclusive. 
The aim of the current study was to determine whether a similar effect could be observed ex vivo in peripheral blood lymphocytes (PBL) isolated from healthy human volunteers, before and following a 3-week dietary intervention with a mixed $\alpha$-carotene- $\beta$-carotene isolate or carotenoid-rich whole foods (cooked carrots or mandarin oranges). These interventions were selected to investigate the effects of carotenoids commonly consumed in the UK and for which marked effects had been observed previously in vitro.

Single-cell gel electrophoresis (SCGE) was employed to measure baseline levels of DNA damage, in the form of SSB, and susceptibility of the DNA to damage from exogenous oxidative insult $\left(\mathrm{H}_{2} \mathrm{O}_{2}\right.$ treatment). SCGE was also used to monitor changes in the numbers of SSB over a time course in both unchallenged and $\mathrm{H}_{2} \mathrm{O}_{2}$-treated PBL. This approach provided indications of the rates of DNA repair for the different lesions. However, interpretation of these results is complex, both as a result of the potential for production of additional oxidative DNA SSB during the course of the experiment and the possible production of SSB as intermediates in the repair of oxidised bases, particularly in PBL. Thus, to complement the SCGE approaches, the enzymatic capacity for repair of different types of DNA oxidative lesions (repair patch synthesis activity for SSB and oxidised bases) was measured in PBL extracts by application of two related cell-free assays (Elliott et al. 2000).

\section{Subjects and methods}

\section{Dietary intervention}

The Institute of Food Research Ethics Committee gave approval for the study. Informed consent was obtained from sixty-four male volunteers (age 18-50 years, nonsmokers, not taking regular medication or dietary supplements, not consuming $>200 \mathrm{~g}$ alcohol per week (UK 28 units, USA 14 units)). Volunteers whose fasting blood glucose or total plasma cholesterol were $>6.1 \mathrm{mmol} / 1$ or $>5.8$ (SD 0.2 ) mmol/l respectively were excluded. Volunteers were assigned randomly to one of the five dietary intervention regimens described later.

One group of volunteers was given a daily portion $(200 \mathrm{~g})$ of cooked, minced carrots. The carrots (frozen sliced carrots; J. Sainsbury plc., own brand) were cooked from frozen in boiling water for $10 \mathrm{~min}$, drained and minced using a food processor. Portions (200 g) were weighed and stored at $-20^{\circ} \mathrm{C}$ and their carotenoid and vitamin $\mathrm{E}$ contents were assessed as described later. The volunteers also consumed $5 \mathrm{~g}$ butter with each serving of the carrots, but its contribution to carotenoid and vitamin E content was assumed to be negligible based on data from food tables (approximately $0.1 \mathrm{mg}$ vitamin $\mathrm{E}$ and $0 \cdot 2 \mu \mathrm{g} \beta$-carotene; Southgate, 2002).

A second group was given mixed supplement capsules (one per d with any meal), the contents of which mimicked the $\alpha$-carotene: $\beta$-carotene ratio found in carrots $(3.7 \mathrm{mg}$ $\alpha$-carotene and $8.2 \mathrm{mg} \beta$-carotene per capsule). These capsules also contained $1.75 \mathrm{mg} \alpha$-tocopherol, present in the carrier oil. A third group received a matched placebo for the carotene capsules (containing $0.06 \mathrm{mg} \alpha$-tocopherol and $0.23 \mathrm{mg} \gamma$-tocopherol).

The fourth group was given tinned mandarin oranges in mandarin orange juice (one $298 \mathrm{~g}$ can per d; J. Sainsbury plc., own brand). The final group was given $60 \mathrm{mg}$ vitamin C (J. Sainsbury plc., own brand; $60 \mathrm{mg}$ tablets) one taken every other day. Thus, the increase in vitamin $\mathrm{C}$ for both groups (mandarin orange and vitamin $\mathrm{C}$ control) over the period of the study was identical.

For the groups of volunteers given the capsules or tablets, the study was performed in a single-blind format. Obviously, this was not possible for the volunteers given the whole foods. All the volunteers were asked to consume the food or supplement for a 3-week period, but otherwise maintain their usual diet throughout the study. The volunteers' body weights were measured both at the beginning and end of the intervention and at the end of the study.

\section{Blood sampling, plasma separation and lymphocyte isolation}

Blood samples were taken from volunteers immediately before the intervention period (week 0 ), at the end of the intervention period (week 3 ) and after a 6-week washout period following the intervention (week 9). Each sample $(110 \mathrm{ml})$ was obtained by venepuncture in heparinised tubes after an overnight fast. A few drops were used immediately for blood glucose determination, as described later.

Plasma (from $10 \mathrm{ml}$ heparinised blood) was separated by centrifugation $\left(1000 \mathrm{~g}, 20 \mathrm{~min}, 20^{\circ} \mathrm{C}\right)$, divided into several portions and stored under liquid $\mathrm{N}_{2}$ for subsequent analyses. PBL were isolated from the remaining volume (approximately $100 \mathrm{ml}$ ) of each sample by density gradient centrifugation using LymphoPrep (Nycomed, Birmingham, UK) according to established methods (Boyum, 1983). The PBL were washed with sterile $\mathrm{NaCl}(0.15 \mathrm{~mol} / \mathrm{l})$, pelleted by centrifugation $\left(400 \mathrm{~g}, 20 \mathrm{~min}, 20^{\circ} \mathrm{C}\right)$, re-suspended in Hanks' balanced salt solution (HBBS; Sigma, Poole, UK) and counted using a haemocytometer.

\section{Whole blood and plasma analyses}

Fasting whole-blood glucose concentrations were analysed using BM-Test 1-44 clinical test strips and a Reflolux S reflectance photometer (Boehringer Mannheim Biochemica, Lewes, Sussex, UK). Total cholesterol, HDL-cholesterol and plasma triacylglycerols were determined using appropriate commercial kits (Roche Diagnostic Systems, Welwyn Garden City, Herts., UK) on a COBAS Mira autoanalyser (Roche Diagnostic Systems). Plasma vitamin C and uric acid were determined according to the method of Finglas et al. (1993) and Brookes et al. (2000). Plasma concentrations of six carotenoids (lutein, zeaxanthin, $\beta$-cryptoxanthin, lycopene, and $\alpha$ - and $\beta$-carotene), retinol and $\alpha$-tocopherol were measured simultaneously according to the method of Hart \& Scott (1995).

\section{Food analyses}

Vitamin C. The entire contents of $298 \mathrm{~g}$ cans of mandarin oranges were homogenised and filtered, and metaphosphoric acid added to the filtrates at a final concentration of 
$0.75 \mathrm{~mol} / \mathrm{l}$. The filtrates were analysed as described by Finglas et al. (1993).

Carotenoid. The entire contents of $298 \mathrm{~g}$ cans of mandarin oranges were homogenised and acetone $(20 \mathrm{ml})$ added. The mixtures were vortexed for $1 \mathrm{~min}$ then centrifuged $\left(800 \mathrm{~g}, 5 \mathrm{~min}, 4^{\circ} \mathrm{C}\right)$ and the organic layers removed. The process was repeated until the homogenates were grey-white and the acetone layers had no discernible yellow colour. The acetone fractions for each sample were pooled, filtered and the total volume determined. The solvent from a $1 \mathrm{ml}$ portion was evaporated under a stream of $\mathrm{N}_{2}$ and the dried material subjected to HPLC analysis as described by Hart \& Scott (1995).

Cooked, minced carrots were homogenised, mixed with methanol $(8 \mathrm{ml})$ and incubated at room temperature for $15 \mathrm{~min}$. Chloroform $(8 \mathrm{ml})$ and then water $(5 \mathrm{ml})$ were added with vortexing. Each mixture was centrifuged $\left(800 \mathrm{~g}, 5 \mathrm{~min}, 4^{\circ} \mathrm{C}\right)$ and the chloroform layer removed. More chloroform was added to the homogenates, the mixtures were vortexed and centrifuged as described earlier and the chloroform layer removed. This process was repeated until the vegetable matter was grey-white and the chloroform layer had no discernible colour. The chloroform fractions for each sample were pooled and the total volume determined. The solvent from a $1 \mathrm{ml}$ portion was evaporated under a stream of $\mathrm{N}_{2}$. Samples were analysed by HPLC as described by Hart \& Scott (1995).

\section{Single-cell gel electrophoresis}

Freshly prepared PBL were diluted to $1.5 \times 10^{6}$ cells $/ \mathrm{ml}$ in HBSS $\left(1.5 \times 10^{7}\right.$ cells $/ 10 \mathrm{ml}$ for each sample $)$ and split equally between two $25 \mathrm{~cm}^{2} 50 \mathrm{ml}$ culture flasks. After a $1 \mathrm{~h}$ recovery period at $37^{\circ} \mathrm{C}$, the cells in one flask were treated with $100 \mu \mathrm{mol} \mathrm{H}_{2} \mathrm{O}_{2} / 1\left(5 \mathrm{~min}\right.$ at $\left.4^{\circ} \mathrm{C}\right)$. The cells in the matched flask were treated with an equivalent volume of HBSS. Subsequently, all the cells were maintained at $37^{\circ} \mathrm{C}$. A portion $(400 \mu \mathrm{l})$ of the $\mathrm{PBL}$ suspension was removed from each of the flasks at 0, 120, 180 and 240 min after addition of the $\mathrm{H}_{2} \mathrm{O}_{2}$ or HBSS. These samples were subjected to SCGE analyses under non-u.v. fluorescent light as described previously (Astley et al. 2002).

\section{Cell-free DNA repair enzyme assays}

For cell-free DNA repair assays, the PBL that had been prepared as described earlier were processed further to minimise platelet contamination before cell extraction. For this, PBL $\left(3 \times 10^{7}-4 \times 10^{7}\right)$ in HBSS were pelleted by centrifugation $\left(400 \mathrm{~g}, 20 \mathrm{~min}, 20^{\circ} \mathrm{C}\right)$. The HBSS was aspirated and the cells resuspended in $1 \mathrm{ml}$ fresh HBSS. A density barrier $(\rho 1.063 \mathrm{~g} / \mathrm{ml})$ was produced by mixing 5 vol. Optiprep (600 g/l iodixanol; Robbins Scientific Europe Ltd, Solihull, UK) with 22 vol. sterile $\mathrm{NaCl}(8 \mathrm{~g} / \mathrm{l})$, 4-(2-hydroxyethyl)1-piperazine-ethanesulfonic acid- $\mathrm{NaOH} \quad(10 \mathrm{mmol} / \mathrm{l})$, EDTA $(1 \mathrm{mmol} / \mathrm{l})(\mathrm{pH} 7 \cdot 4)$. The cell suspensions $(1 \mathrm{ml})$ were layered onto $3 \mathrm{ml}$ of this barrier and centrifuged at $350 \mathrm{~g}$ for $15 \mathrm{~min}$ at room temperature. After centrifugation, the liquid, including the platelet-rich layer, was aspirated leaving the PBL pellet.
Extraction of the PBL was performed essentially as described previously (Elliott et al. 2000), but with the following modifications. The extraction process was divided into two stages. The first stage was performed immediately after isolation and further purification of the PBL. The PBL pellet was resuspended in $2 \mathrm{ml}$ ice-cold hypotonic solution (Tris- $\mathrm{HCl}(10 \mathrm{mmol} / \mathrm{l}), \mathrm{pH} 8.0$, EDTA $(1 \mathrm{mmol} / \mathrm{l})$, dithiothreitol $(5 \mathrm{mmol} / \mathrm{l}))$ and placed on ice for $20 \mathrm{~min}$. At the end of this period a cocktail of protease inhibitors was added (leupeptin, pepstatin and chymostatin (SigmaAldrich Chemical Company, Poole, Dorset, UK) at a final concentration of $0.5 \mu \mathrm{g} / \mathrm{ml}$ plus 4-(2-aminoethyl)benzenesulfonylfluoride hydrochloride (AEBSF; Roche Diagnostics Ltd, Lewes, Sussex, UK) to a final concentration of $0.5 \mathrm{mmol} / \mathrm{l}$ ). The cell suspension was homogenised using a Potter-Elverhjem homogeniser. Ice-cold sucrose-glycerol solution $\left(2 \mathrm{ml}\right.$ Tris- $\mathrm{HCl}(50 \mathrm{mmol} / \mathrm{l}), \mathrm{pH} 8.0, \mathrm{MgCl}_{2}$ $(10 \mathrm{mmol} / \mathrm{l})$, dithiothreitol $(2 \mathrm{mmol} / \mathrm{l})$, sucrose $(250 \mathrm{~g} / \mathrm{l})$, glycerol $(500 \mathrm{ml} / \mathrm{l}))$ was added drop-wise with constant stirring. The extracts were snap frozen and stored under liquid $\mathrm{N}_{2}$.

The second stage of the extraction was carried out batchwise using complete sample sets (all three samples from five subjects, with one from each of the intervention groups). This approach was adopted to minimise the potential for artifactual differences arising as a result of possible dayto-day variations in the efficiency of the extraction process.

Each batch of samples was thawed on ice. Neutralised, saturated ammonium sulfate $(0.5 \mathrm{ml})$ was added drop-wise with constant stirring. The samples were then stirred for a further $30 \mathrm{~min}$ on ice before being transferred to polyallomer tubes (code 356562; Beckman Coulter, High Wycombe, Bucks., UK) and centrifuged at $220000 \mathrm{~g}, 4^{\circ} \mathrm{C}$, for $150 \mathrm{~min}$. The clarified cell extracts were transferred to Ultrafree-4 ultrafiltration units (Millipore, Watford, Herts., UK) with a nominal molecular mass cut-off of $10 \mathrm{kDa}$, and centrifuged at $7500 \mathrm{~g}, 4^{\circ} \mathrm{C}$, for $16 \mathrm{~h}$. The concentrated samples $(50-100 \mu \mathrm{l})$ were diluted by the addition of $500 \mu \mathrm{l}$ ice-cold diafiltration buffer ( $2 \mathrm{ml}$ 4-(2-hydroxyethyl)-1-piperazineethanesulfonic acid-KOH $(25 \mathrm{mmol} / \mathrm{l}), \mathrm{pH} 7 \cdot 8, \mathrm{MgCl}_{2}$ $(12 \mathrm{mmol} / \mathrm{l}), 0 \cdot 1 \mathrm{M}-\mathrm{KCl}$, EDTA $(1 \mathrm{mmol} / \mathrm{l})$, dithiothreitol $(2 \mathrm{mmol} / \mathrm{l})$, glycerol $(170 \mathrm{ml} / \mathrm{l}))$ to the ultrafiltration units. The samples were centrifuged for $3 \mathrm{~h}$ at $7500 \mathrm{~g}, 4^{\circ} \mathrm{C}$, to reconcentrate them. This diafiltration process was repeated two more times. The final volumes of the concentrated extracts were determined and then the samples were each divided into 4-5 portions. These were snap frozen on dry ice and stored at $-80^{\circ} \mathrm{C}$. One portion of each sample was used for determination of protein concentration. Portions of these samples were diluted 500-fold with PBS and analysed using a MicroBCA protein assay kit (Pierce Warriner, Chester, Ches., UK).

A second portion of each sample was used for the DNA repair analyses. Here again, the samples were analysed in the same batch-wise fashion as described earlier. In each batch a Molt-17 cell extract was used as a standard, and a previously prepared PBL extract was used as a quality control sample. Repair analyses were performed as described previously (Elliott et al. 2000) using sample extract equivalent to $2 \mu \mathrm{g}$ protein per reaction and an incubation time of $1 \mathrm{~h}$. For each batch, the two different assay systems, employing either Methylene Blue-visible light or iron 
nitrilotriacetate $-\mathrm{H}_{2} \mathrm{O}_{2}$-treated plasmid templates, were performed in parallel. The damage in both plasmids and the differences between the assays have been described fully elsewhere (Elliott et al. 2000). For each of the two assay types, the sample repair activities for each batch were normalised against the mean value calculated for the Molt-17 cell standard sample obtained from all the batches. Intraassay CV were calculated at 6.6 and $4.9 \%(n 5)$ for the Molt-17 cell standard sample for Methylene Blue-visible light or iron nitrilotriacetate- $\mathrm{H}_{2} \mathrm{O}_{2}$-treated plasmid templates respectively. The intra-assay $\mathrm{CV}$ for the PBL quality control samples were 12.8 and $5.3 \%(n 5)$, and the interassay CV were 10.9 and $27 \%(n$ 11) for Methylene Blue-visible light or iron nitrilotriacetate $-\mathrm{H}_{2} \mathrm{O}_{2}$-treated plasmid templates respectively.

\section{Statistical analyses}

Data were analysed using Statistica, version 5.5 (19842000; StatSoft Inc., Tulsa, OK, USA). Unless otherwise stated, one-way ANOVA was used to analyse all data. Where the variance ratio $(F)$ was significant for a given analysis, mean values were compared by two-tailed paired $t$ tests, Student's $t$ tests or Sheffé tests, as appropriate.

The data for BMI, cell-free DNA repair activities and all plasma variables were analysed both within treatment groups to investigate potential changes between samples taken at weeks 0,3 and 9, and between groups at each sample time as appropriate. Literal ages were compared between groups only.

Single-cell gel electrophoresis. Data from duplicate slides were compared using Student's $t$ test. None were demonstrated to be significantly different, and data were combined to calculate the mean \% DNA in the tail portion of the whole comet image (\% tail DNA), which is proportional to the number of SSB present in the genomic DNA. The incidence of SSB and alkali-labile sites at baseline (no $\mathrm{H}_{2} \mathrm{O}_{2}$ ) and after treatment with $\mathrm{H}_{2} \mathrm{O}_{2}$ was examined using one-tailed paired $t$ test. This established whether the difference between lymphocytes at baseline and following oxidative stress was significant. Mean data sets for each treatment in vitro $\left(\mathrm{H}_{2} \mathrm{O}_{2}\right.$ v. no $\left.\mathrm{H}_{2} \mathrm{O}_{2}\right)$ were analysed to determine whether any significant changes in $\%$ tail DNA were evident over the $240 \mathrm{~min}$ time course.

\section{Results}

\section{Food antioxidant contents}

Each portion of carrots contained 10.6 (SD 0.6) $\mathrm{mg} \alpha$-carotene, 22.7 (SD 1.1) $\mathrm{mg} \beta$-carotene and 0.68 (SD 0.1) $\mathrm{mg}$ lutein $(n 6)$. A portion of mandarin oranges contained 4.3 (SD 0.6) $\mathrm{mg} \beta$-cryptoxanthin, 0.19 (SD 0.04) $\mathrm{mg} \alpha$-carotene, 1.2 (SD 0.2) $\mathrm{mg} \beta$-carotene ( $n$ 6) and $35 \mathrm{mg}$ vitamin $\mathrm{C}$ (based on duplicate analyses). All other carotenoids and tocopherols were below detectable limits in these foods.

\section{Volunteers}

After exclusions and dropouts, eleven volunteers given the mixed carotene supplement, eleven volunteers given the additional carrot portions and nine volunteers from each of the other groups completed the study. There was no significant difference between the intervention groups in terms of age or BMI. Neither was there any significant change in body weight within any of the groups over the course of the study (results not shown).

There were no differences between the intervention groups in average concentrations (the mean values of samples taken at weeks 0, 3 and 9) of plasma total cholesterol, HDL-cholesterol or triacylglycerols (results not shown), and no significant changes in any of these variables were detected over the course of the study within any of the groups.

\section{Plasma antioxidants (carotenoids, tocopherols and vitamin C)}

Within each group there were no significant changes in plasma concentrations of $\alpha$-tocopherol, lutein or zeaxanthin over the course of the study. However, unexpectedly, plasma lycopene was found to be significantly elevated in volunteers given the cooked carrots at both weeks 3 and 9 compared with week $0(P=0.001$; results not shown).

There were no significant differences between the groups for any of the plasma components measured at week 0 . However, the dietary interventions did evoke a variety of changes at other time points (Tables 1-4).

Plasma concentrations of vitamin $\mathrm{C}$ changed significantly only in volunteers given the mandarin oranges $(P=0.003)$, although there was a trend towards an increase at week 3 in those volunteers given the vitamin $\mathrm{C}$ tablets $(P=0.092)$ (Table 1). Values had returned to baseline by week 9 , after the 6-week washout period (i.e. statistically no difference between values at weeks 0 and 9).

Plasma concentrations of $\beta$-cryptoxanthin (Table 2 ) changed only in volunteers given the mandarin oranges, with a significant increase only evident at week $3\left(P<10^{-7}\right)$.

There were no significant differences in plasma $\beta$-carotene concentrations (Table 4 ) between any of the groups at weeks 0 or 9 . At week 3 , plasma $\beta$-carotene concentrations were higher in volunteers fed carrots $\left(P<10^{-6}\right)$ and those given the mixed carotene capsules $\left(P<10^{-7}\right)$ than in the placebo control volunteers as well as those taking vitamin $\mathrm{C}$ tablets or consuming the mandarin oranges. However, surprisingly, a significant decrease in plasma concentrations of $\beta$-carotene was observed between weeks 0 (baseline) and 9 (baseline after washout period) in volunteers given the vitamin $\mathrm{C}$ tablets $(P=0.029)$, although the differences within the group between weeks 0 and 3 , and between weeks 3 and 9, did not achieve statistical significance.

Plasma $\alpha$-carotene concentrations (Table 3 ) were significantly elevated at both weeks 3 and 9 in volunteers fed the carrots $\left(P<10^{-7}\right)$ and mixed carotene capsules $\left(P<10^{-8}\right)$ compared with the other intervention groups, in particular the placebo controls.

\section{Single-cell gel electrophoresis analyses}

Baseline levels of SSB did not differ between the intervention groups or within any group at weeks 0,3 or 9 . In the 
Table 1. Plasma concentrations of vitamin C $(\mu \mathrm{mol} / \mathrm{l}) \ddagger \S$

(Mean values with their standard errors)

\begin{tabular}{|c|c|c|c|c|c|c|c|}
\hline \multirow[b]{2}{*}{ Group } & \multirow[b]{2}{*}{$n$} & \multicolumn{2}{|c|}{ Week 0} & \multicolumn{2}{|c|}{ Week 3} & \multicolumn{2}{|c|}{ Week 9} \\
\hline & & Mean & SEM & Mean & SEM & Mean & SEM \\
\hline$\alpha$-Carotene- $\beta$-carotene & 11 & $54 \cdot 0$ & 3.9 & $55 \cdot 2$ & $4 \cdot 3$ & 54.4 & 3.7 \\
\hline Cooked carrots & 11 & $61 \cdot 3$ & $6 \cdot 1$ & 59.5 & $5 \cdot 8$ & 57.5 & $8 \cdot 1$ \\
\hline Mandarin oranges & 9 & $56 \cdot 1$ & $3 \cdot 1$ & $72 \cdot 3^{*} \dagger$ & 4.5 & $58 \cdot 6$ & 4.5 \\
\hline Placebo & 9 & $58 \cdot 7$ & 4.2 & $60 \cdot 0$ & 3.9 & $59 \cdot 3$ & 4.7 \\
\hline Vitamin C tablets & 9 & 64.9 & $2 \cdot \overline{7}$ & $72 \cdot 6 \dagger$ & 3.6 & $64 \cdot 1$ & $5 \cdot 0$ \\
\hline
\end{tabular}

Mean value was significantly different from that at week $0:{ }^{*} P<0.05$.

Mean values were significantly different from those at week 9: $† P<0.05$

$\ddagger$ For details of subjects, supplements and procedures, see pp. 64-65.

$\S$ Values were compared using one-way ANOVA; where the variance ratio $(F)$ was significant for a given

analysis, mean values were compared by two-tailed paired $t$ tests, Student's $t$ tests or Sheffé tests.

Table 2. Plasma concentrations of $\beta$-cryptoxanthin (nmol/l)†‡

(Mean values with their standard errors)

\begin{tabular}{|c|c|c|c|c|c|c|c|}
\hline \multirow[b]{2}{*}{ Group } & \multirow[b]{2}{*}{$n$} & \multicolumn{2}{|c|}{ Week 0} & \multicolumn{2}{|c|}{ Week 3} & \multicolumn{2}{|c|}{ Week 9} \\
\hline & & Mean & SEM & Mean & SEM & Mean & SEM \\
\hline$\alpha$-Carotene- $\beta$-carotene & 11 & $217 \cdot 8$ & $42 \cdot 8$ & $194 \cdot 7$ & $36 \cdot 8$ & $205 \cdot 7$ & 21.4 \\
\hline Cooked carrots & 11 & $182 \cdot 7$ & $36 \cdot 9$ & $146 \cdot 5$ & $30 \cdot 2$ & $177 \cdot 3$ & $37 \cdot 3$ \\
\hline Mandarin oranges & 9 & $249 \cdot 9$ & $79 \cdot 8$ & $1213 \cdot 7^{\star}$ & $172 \cdot 9$ & $348 \cdot 0$ & $44 \cdot 8$ \\
\hline Placebo & 9 & $187 \cdot 8$ & 34.9 & $205 \cdot 0$ & $39 \cdot 7$ & $194 \cdot 7$ & $34 \cdot 8$ \\
\hline Vitamin $\mathrm{C}$ tablets & 9 & $281 \cdot 3$ & $61 \cdot 7$ & 246.9 & $65 \cdot 0$ & $207 \cdot 0$ & $50 \cdot 8$ \\
\hline
\end{tabular}

Mean value was significantly different from that at week $0:{ }^{*} P<0.05$.

$\dagger$ For details of subjects, supplements and procedures, see pp. 64-65

$\ddagger$ Values were compared using one-way ANOVA; where the variance ratio $(F)$ was significant for a given analysis, mean values were compared by two-tailed paired $t$ tests, Student's $t$ tests or Sheffé tests.

Table 3. Plasma concentrations of $\alpha$-carotene (nmol/l)†‡ (Mean values with their standard errors)

\begin{tabular}{|c|c|c|c|c|c|c|c|}
\hline \multirow[b]{2}{*}{ Group } & \multirow[b]{2}{*}{$n$} & \multicolumn{2}{|c|}{ Week 0} & \multicolumn{2}{|c|}{ Week 3} & \multicolumn{2}{|c|}{ Week 9} \\
\hline & & Mean & SEM & Mean & SEM & Mean & SEM \\
\hline$\alpha$-Carotene- $\beta$-carotene & 11 & 144.4 & $25 \cdot 2$ & $1022 \cdot 7^{*}$ & $118 \cdot 1$ & $319 \cdot 7$ & $61 \cdot 8$ \\
\hline Cooked carrots & 11 & $152 \cdot 6$ & $31 \cdot 1$ & $487 \cdot 7^{*}$ & 67.7 & 201.9 & $26 \cdot 9$ \\
\hline Mandarin oranges & 9 & 173.9 & $21 \cdot 6$ & 313.4 & 135.5 & $192 \cdot 7$ & $45 \cdot 1$ \\
\hline Placebo & 9 & $116 \cdot 8$ & $10 \cdot 4$ & $162 \cdot 1$ & 29.5 & $142 \cdot 1$ & $20 \cdot 1$ \\
\hline Vitamin C tablets & 9 & 174.8 & 29.7 & $181 \cdot 8$ & $57 \cdot 2$ & $112 \cdot 3$ & $17 \cdot 8$ \\
\hline
\end{tabular}

Mean values were significantly different from those at weeks 0 and $9:{ }^{\star} P<0.05$.

†For details of subjects, supplements and procedures, see pp. 64-65.

$\ddagger$ Values were compared using one-way ANOVA; where the variance ratio $(F)$ was significant for a given analysis, mean values were compared by two-tailed paired $t$ tests, Student's $t$ tests or Sheffé tests.

absence of exposure to $\mathrm{H}_{2} \mathrm{O}_{2}$, SSB levels were also found to be constant across the $4 \mathrm{~h}$ time course in all intervention groups at each of the sample times (weeks 0, 3 and 9).

In all cases, exposure of PBL to $\mathrm{H}_{2} \mathrm{O}_{2}$ produced a significant increase in SSB. The magnitude of the increase in SSB immediately following exposure to $\mathrm{H}_{2} \mathrm{O}_{2}$ did not differ significantly between any of the intervention groups, or within each group, at weeks 0,3 or 9.

The number of SSB present in the PBL did not decrease significantly over the $4 \mathrm{~h}$ time course following oxidative challenge except in cells isolated at week 3 from volunteers given the carotene isolate (Fig. 1). In these individuals, the number of SSB returned to levels not significantly different from the matched unchallenged cells (i.e. those that had not been exposed to $\mathrm{H}_{2} \mathrm{O}_{2}$ ).

\section{Cell-free DNA repair activities}

DNA repair patch synthesis activity in PBL extracts, measured using either singlet oxygen- or hydroxyl radical-damaged plasmid DNA, was found to vary markedly from volunteer to volunteer (as much as 10-fold). For this reason, the results obtained for each volunteer are shown separately (Figs 2 and 3). It was notable, however, that intra-individual repair capacity (i.e. repair patch synthesis activity in the three different PBL samples analysed from any one individual) was generally much more consistent.

No correlation was evident between baseline (week 0) repair patch synthesis activities and volunteer age, weight, height, BMI or any of the plasma components analysed. 
Table 4. Plasma concentrations of total $\beta$-carotene $($ cis + trans $)(\mathrm{nmol} / \mathrm{l}) \dagger \ddagger$ (Mean values with their standard errors)

\begin{tabular}{|c|c|c|c|c|c|c|c|}
\hline \multirow[b]{2}{*}{ Group } & \multirow[b]{2}{*}{$n$} & \multicolumn{2}{|c|}{ Week 0} & \multicolumn{2}{|c|}{ Week 3} & \multicolumn{2}{|c|}{ Week 9} \\
\hline & & Mean & SEM & Mean & SEM & Mean & SEM \\
\hline$\alpha$-Carotene- $\beta$-carotene & 11 & $377 \cdot 1$ & 68.3 & $1763 \cdot 1^{*}$ & $243 \cdot 7$ & $572 \cdot 1$ & $113 \cdot 6$ \\
\hline Cooked carrots & 11 & $352 \cdot 2$ & 74.1 & $873 \cdot 1^{\star}$ & $110 \cdot 2$ & $452 \cdot 3$ & 55 \\
\hline Mandarin oranges & 9 & $458 \cdot 6$ & 85.8 & $518 \cdot 7$ & 83.7 & $514 \cdot 3$ & 84 . \\
\hline Placebo & 9 & 321.5 & $70 \cdot 0$ & $380 \cdot 7$ & $59 \cdot 8$ & $412 \cdot 4$ & $76 \cdot 9$ \\
\hline Vitamin C tablets & 9 & 481.5 & 78.0 & $420 \cdot 2$ & $76 \cdot 3$ & 374.8 & $59 \cdot 2$ \\
\hline
\end{tabular}

Mean values were significantly different from those at weeks 0 and $9:{ }^{\star} P<0.05$.

†For details of subjects, supplements and procedures, see pp. 64-65.

$\ddagger$ Values were compared using one-way ANOVA; where the variance ratio $(F)$ was significant for a given

analysis, mean values were compared by two-tailed paired $t$ tests, Student's $t$ tests or Sheffé tests.

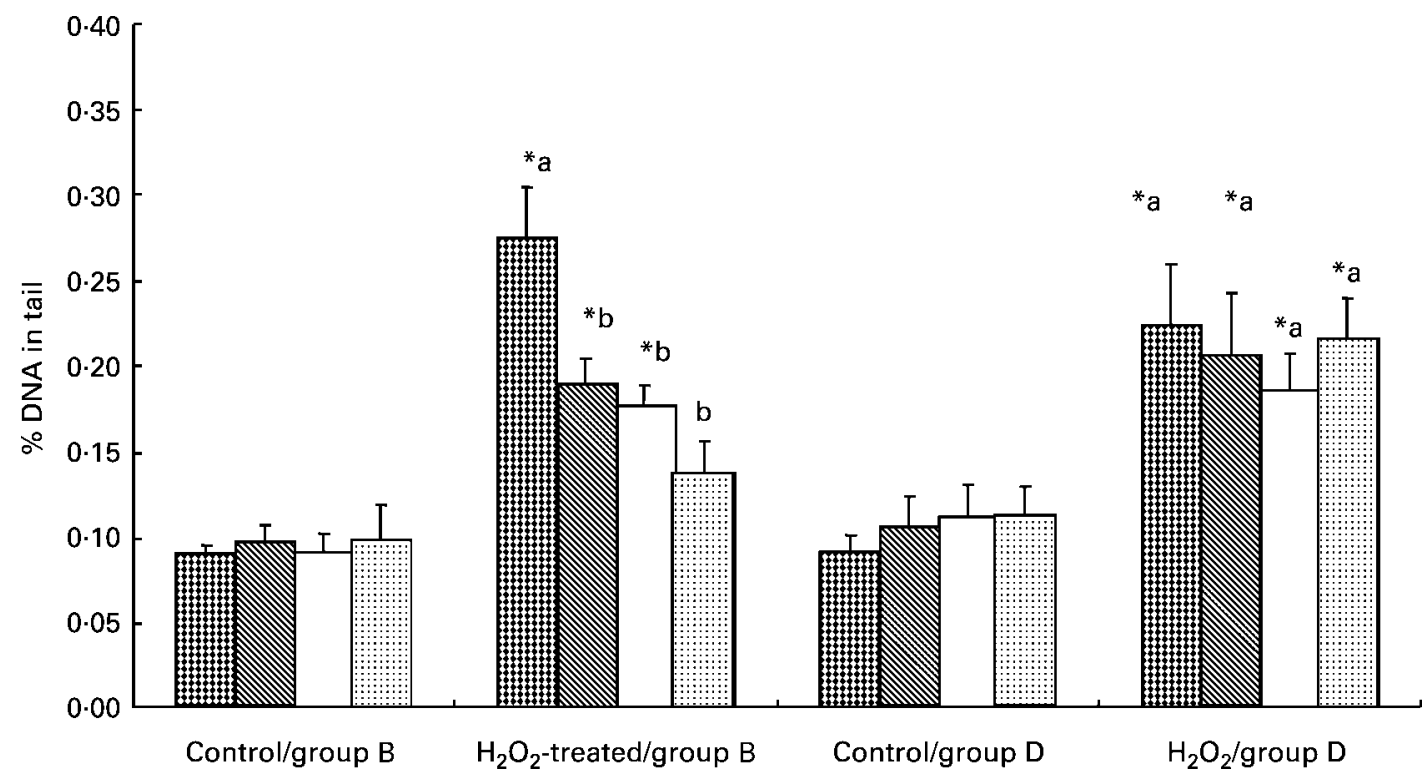

Fig. 1. Single-strand breaks in control (unchallenged) and $\mathrm{H}_{2} \mathrm{O}_{2}$-challenged (at time 0) peripheral blood lymphocytes isolated from volunteers immediately following a 3-week supplementation with an $\alpha$-carotene- $\beta$-carotene mixed capsule (group B) or a matching placebo (group D) at

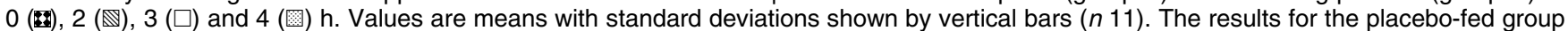
are included both as a control and as a representative example of results obtained for all other dietary interventions and all other time points. For details of subjects and procedures, see pp. 64-65. Mean data sets for each treatment in vitro $\left(\mathrm{H}_{2} \mathrm{O}_{2} v\right.$. no $\left.\mathrm{H}_{2} \mathrm{O}_{2}\right)$ were analysed to determine whether any significant changes in tail moment were evident over the $240 \mathrm{~min}$ time course. Means values were significantly different from those of unchallenged cells: ${ }^{*} P<0 \cdot 05$. ${ }^{\mathrm{a}, \mathrm{b}}$ Mean values with unlike superscript letters were significantly different $(P<0.05)$.

There were no overall differences in DNA repair patch synthesis activities between the intervention groups at any of the three time points measured using either assay. This was not surprising in the light of the substantial inter-individual variation in PBL repair patch synthesis activity.

There was no evidence that dietary intervention with the carotene isolate, its matched placebo, the mandarin oranges or the vitamin $\mathrm{C}$ produced any alteration in DNA repair patch synthesis activity measured using either of the two assay systems. On the other hand, dietary intervention with the cooked carrots did evoke a moderate change in DNA repair patch synthesis activity. In this case, repair activity, as measured with both assay systems, was significantly elevated at the end of the intervention (hydroxyl radical-damaged DNA assay $P=0.035$, singlet oxygendamaged DNA assay $P=0 \cdot 013$ ). No correlation between this increase in repair activity and changes in any of the plasma components measured could be identified.

\section{Discussion}

Dietary supplementation with a mixed $\alpha$-carotene $-\beta$-carotene isolate enhanced the rate of PBL recovery, measured as disappearance of DNA SSB following challenge with $\mathrm{H}_{2} \mathrm{O}_{2}$. The lack of an equivalent enhancement of cellular recovery in PBL isolated from volunteers fed cooked carrots may have been due to the less substantial increases in plasma concentrations of $\alpha$ - and $\beta$-carotene in members of this group. This reflects the fact that, although the $\alpha$-carotene and $\beta$-carotene content of the carrots exceeded the content of the capsules, absorption of the carotenoids from the whole food matrix is less efficient than from the capsules (Jayarajan et al. 1980; Southon \& Faulks, 2001).

In the absence of oxidative challenge, no changes in numbers of SSB were detected in PBL isolated at any time for any of the intervention groups. However, under these conditions, the number of SSB is very low and the assay is being used at the limit of its sensitivity. Thus, 


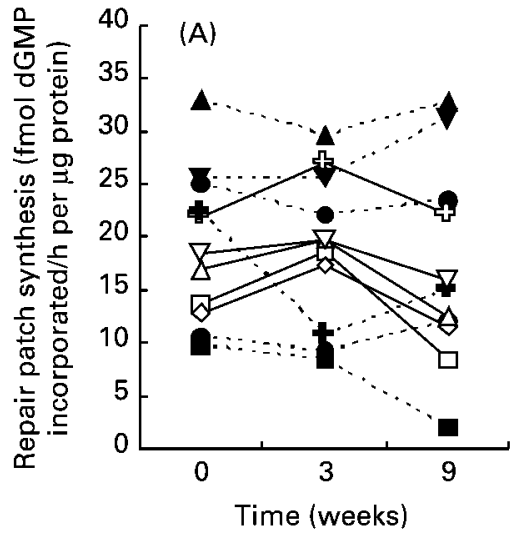

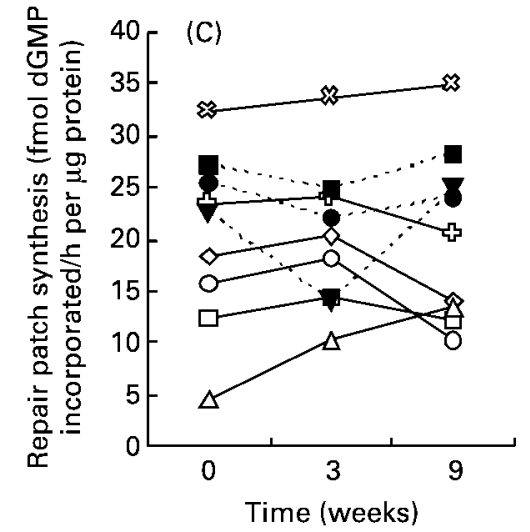
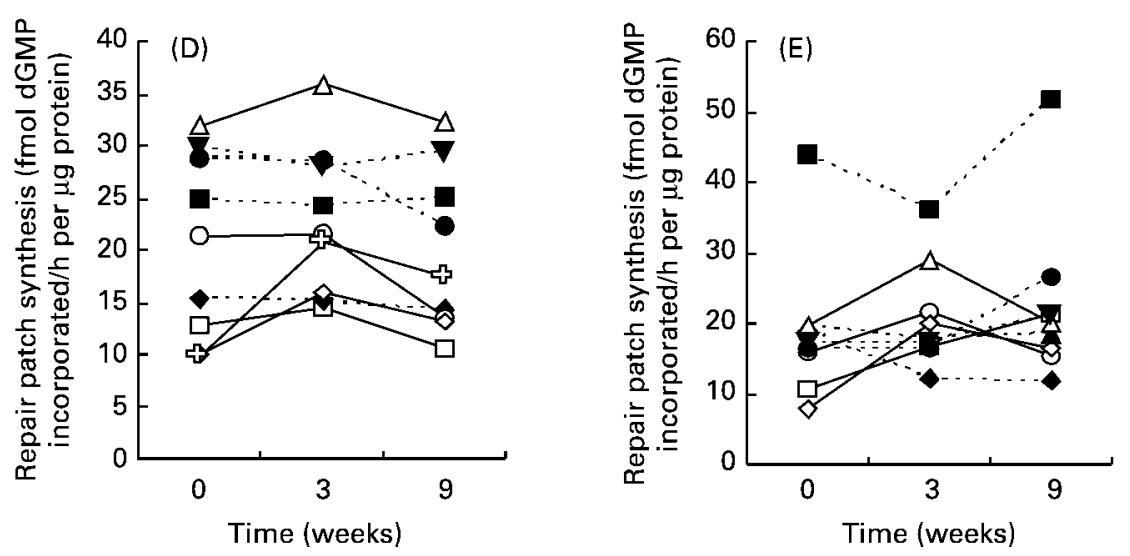

Fig. 2. DNA repair patch synthesis activity measured using singlet oxygen (generated with Methylene Blue and visible light)-damaged template DNA in peripheral blood lymphocytes isolated before (week 0 ) and immediately after (week 3 ) dietary intervention and after a 6-week washout period (week 9). The intervention groups were as follows: $(A)$, cooked carrots $(200 \mathrm{~g} / \mathrm{d})$; $(\mathrm{B})$, mixed $\alpha$-carotene- $\beta$-carotene capsules $(15 \mathrm{mg} / \mathrm{d})$; (C), mandarin oranges (298 g/d); (D), placebo capsule (one per d); (E), vitamin C (60 mg tablet every other day). Repair activity for each volunteer is shown as a line with identical symbols at all three sample times. Different symbols have been used to distinguish between data from individuals. Solid lines with open symbol denote instances where repair activity was higher following intervention than before. Broken lines with closed symbols denote instances where repair activity was unchanged or decreased following intervention. For details of subjects and procedures, see pp. 64-65.

the possible presence of subtle but important differences cannot be ruled out completely.

The enhanced recovery following oxidative challenge in PBL isolated from volunteers following $\alpha$-carotene$\beta$-carotene supplementation mirrors results that we have obtained with a human lymphocyte cell line (Molt-17) supplemented with carotenoids in vitro (Astley et al. 2002) and that others have observed in PBL from human volunteers following either a single large oral dose of $\beta$-carotene or a 1-week dietary supplementation with $\beta$-carotene (Fillion et al. 1998; Torbergsen \& Collins, 2000).

It is not possible with any techniques currently available to define the mechanism responsible for this enhanced recovery with certainty. However, two possible interpretations are immediately obvious. The first is that increased cellular carotenoids act to enhance the DNA SSB repair. The second, favoured by other authors, is that carotenoids taken up by the cells provide a degree of protection for cellular DNA against further DNA damage being generated over the protracted time course following exposure to $\mathrm{H}_{2} \mathrm{O}_{2}$ (Fillion et al. 1998; Torbergsen \& Collins, 2000).

A third, less apparent, explanation arises from the fact that SSB are produced as intermediates during the repair of oxidised bases in DNA. Thus, alterations in the rates of production and removal of such intermediates could affect the apparent rate of cellular recovery from oxidative challenge, measured as disappearance of DNA SSB. However, there was no evidence of changes in DNA repair patch synthesis activity in PBL isolated from volunteers following dietary supplementation with $\alpha$-carotene$\beta$-carotene. The singlet oxygen-damaged DNA, which is used as the repair template for one of these assays, contains almost exclusively oxidised bases. In this case, repair patch synthesis only takes place following excision of base lesions, generation of SSB and removal of the $3^{\prime}$ blocking groups in the SSB. The absence of any detectable change in the activity measured with this assay provides a strong indication that there were no alterations in the enzyme activities for each of the preceding steps as a result of dietary supplementation with the mixed carotene capsules.

In addition, the results presented here are not consistent with the $\alpha$-carotene- $\beta$-carotene acting to enhance cell recovery by providing direct antioxidant protection over the time course following oxidative challenge. First, there was no evidence of additional direct antioxidant protection afforded to the cellular DNA immediately after exposure to 


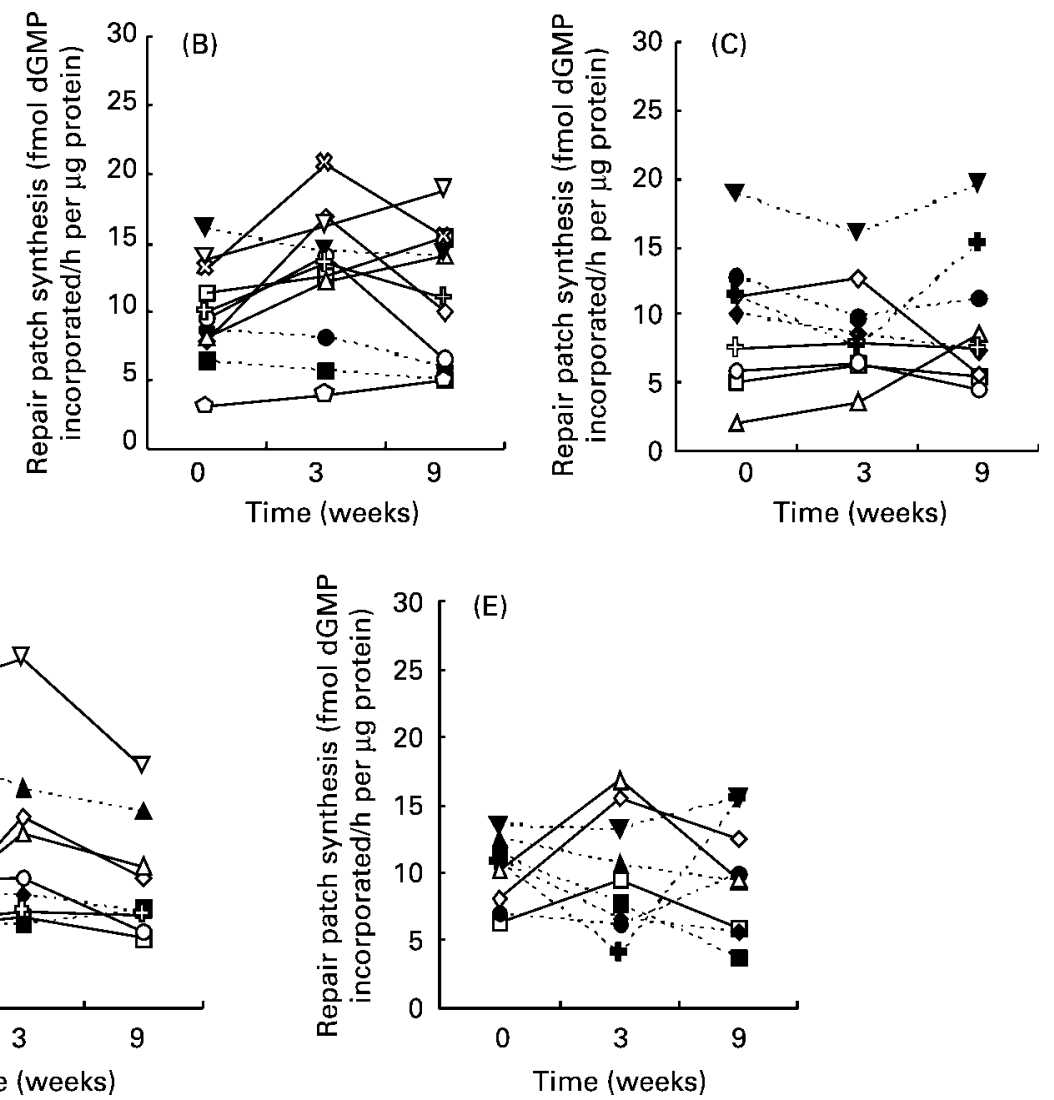

Fig. 3. DNA repair patch synthesis activity measured using hydroxyl radical (generated with iron nitrilotriacetate and $\mathrm{H}_{2} \mathrm{O}_{2}$ )-damaged template DNA in peripheral blood lymphocytes isolated before (week 0) and immediately after (week 3) dietary intervention and after a 6-week washout period (week 9). The intervention groups were as follows: $(A)$, cooked carrots $(200 \mathrm{~g} / \mathrm{d})$; (B), mixed $\alpha$-carotene- $\beta$-carotene capsules $(15 \mathrm{mg} / \mathrm{d})$; (C), mandarin oranges ( $298 \mathrm{~g} / \mathrm{d})$; (D), placebo capsule (one per d); (E), vitamin C (60 mg tablet every other day). Repair activity for each volunteer is shown as a line with identical symbols at all three sample times. Different symbols have been used to distinguish between data from individuals. Solid lines with open symbols denote instances where repair activity was higher following intervention than before. Broken lines with closed symbols denote instances where repair activity was unchanged or decreased following intervention. For details of subjects and procedures, see pp. 64-65.

$\mathrm{H}_{2} \mathrm{O}_{2}$ in PBL from $\alpha$-carotene- $\beta$-carotene supplemented volunteers. Direct protective effects have been observed previously with vitamin $\mathrm{C}$, carotenoid supplements and carotenoid-rich foods (Duthie et al. 1996; Astley, 1997; Collins et al. 1998; Lowe et al. 1999; Riso et al. 1999; Porrini \& Riso, 2000). However, carotenoids have been shown to be capable of producing both anti- and pro-oxidant effects, as well as no net effect, in relation to DNA SSB in vitro (Lowe et al. 1999). The balance between the different effects depends on the carotenoid concentrations and model systems used (Woods et al. 1999). Thus, the lack of observed antioxidant effect by the carotenoids or vitamin $\mathrm{C}$ in the current study does not necessarily contradict other previous studies.

The second point, which suggests that the enhancement of cellular recovery was unlikely to be due to the carotenoids providing significant antioxidant protection, is that dimethylsulfoxide was added to the cells immediately after treatment with $\mathrm{H}_{2} \mathrm{O}_{2}$. Dimethylsulfoxide is an effective hydroxyl radical scavenger (Repine et al. 1981). At the concentration used $(10 \mathrm{ml} / 1,128 \mathrm{mmol} / \mathrm{l})$ it is likely that the antioxidant protection afforded by the dimethylsulfoxide would swamp any provided by the much lower concentrations of the carotenoids in the cells (Astley et al. 2002). It is possible that the different sub-cellular distributions of the lipophilic carotenoids and dimethylsulfoxide could elicit distinct antioxidant effects. However, dimethylsulfoxide is capable of both cytosolic and cell membrane interaction (Halliwell \& Gutteridge, 1991) and should be as well, if not better, located within cells to protect nuclear DNA from oxidants.

Consequently, the results presented here are most consistent with the $\alpha$-carotene- $\beta$-carotene capsule dietary supplements specifically leading to an increase in DNA SSB repair activity. The suggestion that a dietary antioxidant is also able to modulate DNA repair via redox-sensitive pathways that ultimately influence nucleotide or base excision repair, or transcription-coupled repair, is not new (Cooke et al. 1998; Lunec et al. 2002). It has been claimed that Vitamin $\mathrm{C}$ has a novel function, quite apart from its direct antioxidant ability (Cooke et al. 2001), in modifying DNA repair mechanisms; in addition to simply scavenging free radicals, this function could be responsible for its anti-cancer properties. Increasingly, the carotenoids are also being acknowledged as possessing other biological activities (Bendich \& Olson, 1989). 
Using the cell-free repair assays, no enhancement of DNA repair patch synthesis activity was apparent in extracts from PBL isolated from volunteers immediately following dietary supplementation with the $\alpha$-carotene$\beta$-carotene capsules. The same was true for the human lymphocyte cell line supplemented in vitro with a range of carotenoids (Astley et al. 2002). This suggests that if the $\alpha$-carotene- $\beta$-carotene isolate does indeed influence DNA repair processes in vivo, it does so at a step that is independent of the processes involved in the synthesis of the DNA repair patches incorporated during the base excision repair and SSB repair processes. One candidate process is the strand break re-ligation step, which is downstream of the patch synthesis in the repair process. The development of new methods capable of measuring the kinetics of different steps in the SSB repair pathway will be required to confirm or exclude this possibility.

Although dietary supplementation with the $\alpha$-carotene$\beta$-carotene capsules did not provoke any alteration in DNA repair patch synthesis activity, dietary supplementation with cooked carrots, rich in these same carotenoids, did increase the repair activity moderately. This suggests that other components of the whole food may be important in modulating DNA repair processes, either separately from or in conjunction with the carotenoids. Alternative and/or contributing factors that could explain this apparent discrepancy, and the lack of effect of vitamin $\mathrm{C}$, include duration and dose, comparative bioavailability and the time point of testing, as discussed by Cooke et al. (2002).

In summary, dietary supplementation with mixed carotene capsules, at a level achievable by dietary manipulation alone without the use of isolates, led to an enhancement of cellular recovery from oxidative challenge, measured as the disappearance rate of $\mathrm{H}_{2} \mathrm{O}_{2}$-induced DNA SSB, in PBL. This effect was most consistent for the mixed carotenoid intervention promoting cellular SSB repair processes. Carotenoid-rich whole foods did not elicit the same effect, possibly due to the fact that they produced a less marked rise in plasma carotenoids. On the other hand, one of the whole foods, cooked carrots, did lead to a moderate but significant increase in DNA repair patch synthesis activity in PBL. Indeed, the observed wide inter-individual variation in PBL DNA repair patch synthesis activity, which could not be linked to any of the volunteers' variables measured, suggests that either genetic or environmental factors, or both, are important for the regulation of DNA repair processes. The results presented here suggest that diet may be one such factor. Such modulation of DNA repair activity potentially has great significance in relation to degenerative processes and human health.

\section{Acknowledgements}

The work was supported by the former Ministry of Agriculture Fisheries and Food (now represented in this area by the Food Standards Agency), UK, and performed at the Institute of Food Research, Colney, Norwich, UK. The authors would like to thank Tony Wright for his help with the statistical analyses.

\section{References}

Ames BN (1989) Endogenous oxidative DNA damage, aging, and cancer. Free Radic Res Commun 7, 121-128.

Astley SB (1997) Limitation of DNA damage: the role of carotenoids and alpha-tocopherol from the diet. PhD Thesis, University of East Anglia.

Astley SB, Elliott RM, Archer DB \& Southon S (2002) Increased cellular carotenoid levels reduce the persistence of DNA single-strand breaks after oxidative challenge. Nutr Cancer 43, 202-213.

Bendich A \& Olson JA (1989) Biological actions of carotenoids. FASEB J 3, 1927-1932.

Block G, Patterson B \& Subar A (1992) Fruit, vegetables, and cancer prevention: a review of the epidemiological evidence. Nutr Cancer 18, 1-29.

Boyum A (1983) Isolation of human blood monocytes with Nycodenz, a new non-ionic iodinated gradient medium. Scand $J$ Immunol 17, 429-436.

Brookes M, McMunn A, Sprunt J, Finglas PM \& Gibb I (2000) Quality Control of Blood and Saliva Analytes. 2000. Joint Health Surveys Unit. The Scottish Health Survey 1998. Edinburgh: The Scottish Executive Department of Health.

Byers T \& Perry G (1992) Dietary carotenes, vitamin C, and vitamin $\mathrm{E}$ as protective antioxidants in human cancers. Annu Rev Nutr 12, 139-159.

Collins AR, Olmedilla B, Southon S, Granado F \& Duthie SJ (1998) Serum carotenoids and oxidative DNA damage in human lymphocytes. Carcinogenesis 19, 2159-2162.

Cooke MS, Evans MD, Mistry N \& Lunec J (2002) Role of dietary antioxidants in the prevention of in vivo oxidative DNA damage. Nutr Res Rev 15, 19-41.

Cooke MS, Evans MD, Podmore ID, et al. (1998) Novel repair action of vitamin $\mathrm{C}$ upon in vivo oxidative DNA damage. FEBS Lett 439, 363-367.

Cooke MS, Podmore ID, Evans MD \& Lunec J (2001) Antioxidant properties of vitamin C: New Issues. Cancer Detect Prev 25, 565-567.

Duthie SJ, Ma A, Ross MA \& Collins AR (1996) Antioxidant supplementation decreases oxidative DNA damage in human lymphocytes. Cancer Res 56, 1291-1295.

Elliott RM, Astley SB, Southon S \& Archer DB (2000) Measurement of cellular repair activities for oxidative DNA damage. Free Radic Biol Med 28, 1438-1446.

Fillion L, Collins A \& Southon S (1998) Beta-carotene enhances the recovery of lymphocytes from oxidative DNA damage. Acta Biochim Pol 45, 183-190.

Finglas PM, Bailey A, Walker A, Loughridge JM, Wright AJ \& Southon S (1993) Vitamin C intake and plasma ascorbic acid concentration in adolescents. Br J Nutr 69, 563-576.

Guyton KZ \& Kensler TW (1993) Oxidative mechanisms in carcinogenesis. Br Med Bull 49, 523-544.

Halliwell B (1994) Free radicals and antioxidants: a personal view. Nutr Rev 52, 253-265.

Halliwell B \& Gutteridge JMC (1991) Free Radicals in Biology and Medicine, 2nd ed. Oxford: Oxford University Press.

Hart DJ \& Scott KJ (1995) Development and evaluation of an HPLC method for the analysis of carotenoids in foods, and the measurement of the carotenoid content of vegetables and fruit comonly consumed in the UK. Food Chem 54, $101-111$.

Jayarajan P, Reddy V \& Mohanram M (1980) Effect of dietary fat on absorption of beta carotene from green leafy vegetables in children. Indian J Med Res 71, 53-56.

Lowe GM, Booth LA, Young AJ \& Bilton RF (1999) Lycopene and beta-carotene protect against oxidative damage in HT29 cells at low concentrations but rapidly lose this capacity at higher doses. Free Radic Res 30, 141-151. 
Lunec J, Holloway KA, Cooke MS, Faux S, Griffiths HR \& Evans MD (2002) Urinary 8-oxo-2' deoxyguanosine: Redox regulation of DNA repair in vivo? Free Radic Biol Med 33, $875-885$.

Porrini M \& Riso P (2000) Lymphocyte lycopene concentration and DNA protection from oxidative damage is increased in women after a short period of tomato consumption. J Nutr 130, 189-192.

Repine JE, Pfenninger OW, Talmage DW, Berger EM \& Pettijohn DE (1981) Dimethyl sulfoxide prevents DNA nicking mediated by ionizing radiation or iron/hydrogen peroxide-generated hydroxyl radical. Proc Natl Acad Sci USA 78, $1001-1003$.

Riso P, Pinder A, Santangelo A \& Porrini M (1999) Does tomato consumption effectively increase the resistance of lymphocyte DNA to oxidative damage? Am J Clin Nutr 69, 712-718.

Southgate DAT (2002) McCance and Widdowson's The Composition of Foods, 5th ed. Cambridge: Royal Society of Chemistry/CRC Press.
Southon S \& Faulks R (2001) Predicting the bioavailability of antioxidants in food: the case of carotenoids. In Antioxidants in Food: Practical Applications, pp. 124-143 [J Pokorny, $\mathrm{N}$ Yanishlieva and $\mathrm{M}$ Gordon, editors]. Cambridge: CRC Press/Woodhead Publishing Ltd.

Torbergsen AC \& Collins AR (2000) Recovery of human lymphocytes from oxidative DNA damage; the apparent enhancement of DNA repair by carotenoids is probably simply an antioxidant effect. Eur J Nutr 39, 80-85.

Wiseman H \& Halliwell B (1996) Damage to DNA by reactive oxygen and nitrogen species: role in inflammatory disease and progression to cancer. Biochem J 313, Part 1, 17-29.

Woods JA, Bilton RF \& Young AJ (1999) Beta-carotene enhances hydrogen peroxide-induced DNA damage in human hepatocellular HepG2 cells. FEBS Lett 449, 255-258.

World Cancer Research Fund (1997) Food Nutrition and the Prevention of Cancer: A Global Perspective. Washington, DC: American Institute for Cancer Research. 